\title{
MEGALOBLASTIC ANAEMIA IN HAEMOCHROMATOSIS
}

\author{
P. J. ToghiLl, M.B., M.R.C.P., M.R.C.P. (Ed.) \\ Medical Registrar, University College Hospital, W.C.1.
}

IN 1877 Müller described a marked bronzed discoloration of the skin in some patients considered to have pernicious anæmia. This observation, confirmed later by Immerman (1879) is likely to be the first record of an association between a macrocytic type of anæmia and hæmochromatosis. Since that time French (1909), Roth (1915), Bork (1928), Cain (1940), Hotz (1944) and Harvier and Mallarmé (1938) have all described similar findings.

In reporting nine more cases with this association Koszewski (1952) suggested that the macrocytic megaloblastic anæmia complicating hæmochromatosis might not be true pernicious anæmia, and more recently Granville and Dameshek (1958) have been able to obtain an excellent clinical and hæmatological response to therapy with folic acid in a subject with hæmochromatosis and this type of anæmia, as have Brunner and Frick (1963) who also studied two similar cases which responded specifically to folic acid therapy.

Two more cases in which megaloblastic erythropoiesis has complicated hæmochromatosis have been seen but in these two patients the anæmia has been refractory to both vitamin $B_{12}$ and folic acid therapy.

\section{Case No. 1}

Mr. A.T.G., 63, was referred to the Royal Infirmary, Sheffield, in June, 1960, for investigation of a refractory megaloblastic anæmia. He gave a three year history of increasing breathlessness, weak ness of the legs and paræsthesiæ of the hands and feet. He had received regular injections of Vitamin $B_{12}$ and oral folic acid during the preceding 12 months without any subjective or hæmatological improvement.

Examination revealed a pale man with no clinical icterus. The skin was not pigmented, hair distribution was normal, there was no palmar erythema, and no spider nævi were seen. The liver was easily palpable 3 fingers-breadth below the right costal margin, being firm and regular. The spleen was not palpable. There was no ascites and no dilated veins were seen on the abdominal wall. There were no abnormal signs in the central nervous system.

Investigations: Hb. 9.1 g. \%. Many of the red cells were target cells, with the remaining cells being either normochromic and normocytic or hypochromic and microcytic. Occasional cells were macrocytic. The white cells and platelet counts were normal. The bone marrow showed megaloblastic erythropoiesis. Free gastric hydrochloric acid was present. Total serum bilirubin $1.0 \mathrm{mg} . \%$. The urine contained no excess of bilirubin or urobilinogen. Bromsulphthalein retention test showed blood levels of 33,30 and $18 \%$, remaining at 30, 45 and 60 minutes. Serum albumin level 5.1 g.\%. Electrophoresis showed a diffuse increase in the $\gamma$-globulin. Liver biopsy showed $\stackrel{\mathbb{Q}}{\Omega}$ evidence of hæmochromatosis.

The serum iron was $265 \mu \mathrm{g} / \mathrm{ml}$, total iron binding capacity $275 \mu \mathrm{g} . / \mathrm{ml}$. A glucose tolerance curve gave a fasting level of $89 \mathrm{mg}$. $/ 100 \mathrm{ml}$. with figures of$150,205,208,165$ and 130 at each successive half- $\omega$ hour interval with no glycosuria. Fæcal fat excretions normal.

Two 24-hour urine specimens after a $10 \mathrm{~g}$. tryptophane load contained only 3 and $8 \mathrm{mg}$. xanthurenic. acid, thus demonstrating no evidence of pyridoxine deficiency.

Progress. Since 1960 this man has remained in fair t health with a steady hæmoglobin level of $9-10 \mathrm{~g} . \% .0$ In 1963 he was given a course of parenteral folic acid $5 \mathrm{mg}$. twice weekly for 3 months without any? further improvement.

Case No. 2

Lt.-Col. H.D.M., 61, was admitted to University College Hospital in October, 1962, for investigation of a refractory megaloblastic anæmia.

During the preceding 18 months he had becofeincreasingly tired, lethargic, short of breath, ands had had some ankle swelling. In April, 1962, $\mathrm{Ee}^{\mathrm{G}}$ was found, in another hospital, to have a me $-\square$ loblastic macrocytic anæmia. Treatment with injectiontso of Vitamin $B_{12}$ and later folic acid orally, $5 \mathrm{mg}$. q.d.s., for several months, together with blood transfusions, $\overline{0}$ failed to improve his condition.

Examination revealed him to be clinically anæmic. $\frac{\mathrm{D}}{\mathrm{D}}$ The skin was not pigmented, body hair was scanty but of normal distribution, there was no palmar $\overrightarrow{\vec{\sigma}}$ erythema, and no spider nævi were seen. There was 3 no glossitis. Abdominal examination was normal, neither the liver nor the spleen were palpated.

Investigations. Initial hæmatological findings showed: Hb. 11.7 g. \%, RBC 3,600,000, CI 1.0, MCDO 7.1 , MCV $100 \mu^{3}$, MCHC $32 \%$. The red cells showed marked anisocytosis and moderate hypochromia. WBC 4,100 cu. mm., normal differential. Platelets 3 . present in normal numbers. Reticulocyte count $0.5 \%$ Bone marrow examination showed a highly cellularo marrow with megaloblastic erythropoiesis. Augmented histamine test showed the presence of freeo acid. No excess of FIGLU (formimino-glutamic acid) or urocanic acid after histidine loading. Serum folic acid activity $25 \mathrm{~m} \mu \mathrm{g}$./ $\mathrm{ml}$. (normal range $5.6-$ $23 \mathrm{~m} \mu \mathrm{g} . / \mathrm{ml}$.). Direct Coombs' test negative. Serum bilirubin $1.7 \mathrm{mg} . \%$, direct reaction negative. Urines showed no excess of bilirubin or urobilinogen. Serumn proteins-total $6.5 \mathrm{~g} . \%$ (albumin $4.0 \mathrm{~g}$;, globulin 2.5 g.). Electrophoresis showed a small increase incw the $\alpha_{2}$-globulin. Empirical liver function tests normal Serum iron $181 \mu \mathrm{g} . / \mathrm{ml}$. $100 \%$ saturation. Urine-no glucose detected on initial examination. Barium meale and follow-through showed a normal stomach $\$$ duodenum and small intestine. Fæcal fat excretion ${ }^{-}$ normal.

Progress. In view of the failure of this anæmiao to respond to either folic acid or vitamin $B_{12}$, the 
patient was given steroid therapy, in the form of prednisolone, $15 \mathrm{mg}$. q.d.s., and testosterone, $50 \mathrm{mg}$. q.d.s. This former drug provoked an acute diabetic state which required treatment with diet and insulin. In spite of repeated transfusions his condition deteriorated and he died in February, 1963.

Necropsy (Dr. P. M. Sutton). This showed clearly defined evidence of hæmochromatosis. The liver weighed $2680 \mathrm{~g}$. and on section was deep bronze in colour with early fibrosis. Histology of the liver showed pigment cirrhosis with no infiltration. The pancreas was fibrotic and microscopy revealed iron pigment in both islets and acini. The spleen was enlarged $(510$ g.) with ante-mortem thrombus in the splenic vein. The lumbar spine and left femur contained hypercellular bone marrow showing megaloblastic erythropoiesis.

\section{Discussion}

Although many of the earlier writers ascribed the macrocytic type of anæmia associated with hæmochromatosis to pernicious anæmia, it seems likely from more recent work that this is incorrect.

Koszewski (1952) considered that the morphological changes in the peripheral blood in his patients differed from that expected in true pernicious anæmia because there was less anisocytosis and poikilocytosis and only two out of his nine patients showed any real reticulocyte response to crude liver extract. Granville and Dameshek (1958) were able to exclude vitamin $B_{12}$ deficiency' as an ætiological factor in their patient by failing to obtain any hæmatological response with parentral vitamin $\mathrm{B}_{12}$; furthermore, the presence of free gastric hydrochloric acid excluded the possibility of an associated pernicious anæmia. Brünner and Frick (1963) also confirmed this by using ${ }^{58} \mathrm{Co}$. labelled $\mathrm{B}_{12}$ in the studies in their two patients to demonstrate normal $B_{12}$ utilisation, before obtaining good clinical and hæmatological responses with folic acid.

The prevalence of macrocytosis in patients with hepatic disease is well known, but megaloblastic erythropoiesis is rare (Jandl, 1955). It has been shown that patients with hepatic cirrhosis and megaloblastic erythropoiesis have normal serum $B_{12}$ levels and show marked clinical and hæmatological responses to small doses of folic acid (Jandl and Lear, 1956). More recently it has been suggested that folic acid deficiency in liver disease may be primary or secondary. In the primary form there is a total body deficit, whereas in the secondary form the body stores are normal, but there may be a failure of utilisation of folic acid. In this latter form the liver enzymes are defective and folic acid is not converted to active folinic acid forms (Carter, Heller, Schaffner and Korn, 1961). Thus in hæmochromatosis the hepatic cirrhosis may be responsible for either a primary or a secondary folic acid deficiency.

There is also the theoretical possibility of impaired absorption. of folic acid in hæmochromatosis due to the extensive deposits of hæmosiderin in the intestinal mucosa. As a result, in hæmochromatosis, there may be both a defective absorption of folic acid and a secondary inadequate storage and utilisation of folic acid due to impairment of liver function. These features suggest that the anæmia in hæmochromatosis could be due to a folic acid deficiency and this contention receives the support of the cases described by Granville and Dameshek (1958) and Brünner and Frick (1963).

In the two cases described in this paper the pathogenesis of the megaloblastic anæmia is complex and therapy has not been successful in restoring hæmopoiesis to normal. In Case 1 there was no response to large doses of parenteral $\mathbf{B}_{12}$ and oral and parenteral folic acid. Pyridoxine deficiency, described as being responsible for anæmia in hæmochromatosis (Maier, 1957), was excluded by a tryptophane loading test. In Case 2 , in whom the diagnosis of hæmochromatosis was established only after death, parenteral vitamin $B_{12}$ and oral folic acid were given. Parenteral folic acid was not administered in this case but the finding of a normal serum folic acid level and a normal excretion of FIGLU after histidine loading probably excludes any primary deficiency. It seems unlikely that the hæmosiderosis of the intestinal mucosa could prevent all absorption of folic acid particularly when large doses of folic acid were being administered in relation to the tiny physiological requirements which have been estimated as being approximately $50 \mu \mathrm{g}$./day. (Herbert, 1962).

It would appear, therefore, that the megaloblastic anæmia which sometimes complicates hæmochromatosis may be unresponsive to folic therapy. This suggests that there is a secondary deficiency of folic acid which is presumably due to an enzyme block in the utilisation pathway of folic acid in the liver to active folinic acid forms.

\section{Summary}

Two patients are described in whom megaloblastic erythropoiesis occurred in association with hæmochromatosis. In both cases the anæmia was resistant to treatment with both vitamin $B_{12}$ and folic acid. The mechanisms in the production of this type of anæmia are discussed.

I thank Prof. T. A. J. Prankerd, Dr. E. K. Blackburn and Dr. H. P. Brody for permission to publish these cases. I am also grateful to Prof. Prankerd for reading the script and for his helpful criticisms.

\section{REFERENCES}

BORK, K. (1928): Zur Lehre von der Allgemeinen Hämochromatose, Virchows Arch. path. Anat., 269, 178.

BRUNNER, H, and Frick, P. (1963): Megaloblastic Folic Acid Deficiency Anæmia in Hæmochromatosis, a communication to the Swiss Soc. of Int. Med.

CAIN, J. C. (1940): Hæmochromatosis, Report of 6 Cases, Tex. St. J. Med., 36, 356.

Carter, F. C., Heller, P., Schaffner, G., and KorN, R. J. (1961): Formimino-glutamic acid (FIGLU) 
Excretion in Hepatic Cirrhosis, A.M.A. Arch. intern. Med., 108, 41.

FreNCH, H. (1909): Sixty Cases of Pernicious Anæmia, Guy's Hosp. Rep., 63, 2.

Granville, N., and DAMESHEK, W. (1958): Hæmochromatosis with Megaloblastic Anæmia. Response to Folic Acid Therapy, New Engl. J. Med., 258, 586.

HaRvier, P., and MallaRme, J. (1938): Biermer Disease of Hepatomegalic Form with Pigmentations Simulating Pigmentary Cirrhosis, Sang., 12, 883.

HerberT, V. (1962): Minimal Daily Adult Folate Requirement, A.M.A. Arch. intern. Med., 110, 649.

HoTZ, H. W. (1944): Lebercirrhose und Hämatopose, Ergebn. inn. Med. Kinderheilk, 64, 198.

ImmermanN, H. (1879): Ueber Progressive Perniziöse Anämie, Dtsch. Arch. klin. Med., 13, 209.
JANDL, J. H. (1955): The Anæmia of Liver Disease, Observations on its Mechanism, J. clin. Invest., $\frac{3}{12}$
34, 390.

JANDL, J. H., and LEAR, A. A. (1956): Metabolisme. of Folic Acid in Cirrhosis, Ann. intern. Med., 45, 1027.

KoszewSKI, B. J. (1952): The Occurrence of Megalo blastic Erythropoiesis in Patients with Hemochromatosis, Blood, 7, 1182.

MAIER, C. (1957): Hyperchromic Anæmia in $\frac{\bar{m}}{\frac{1}{2}}$ Hæmochromatosis caused by Vit. $\mathbf{B}_{6}$ Deficiency, Schweiz. med. Wschr., 87, 39.

Muller, H. (1877): "Die Progressive Perniziöseê

Anämie, Zürich: Schmidt.
RoTH, O. (1915): Zur Pathogenese und Klinik der $\vec{\circ}$ Hämochromatose, Dtsch. Arch. klin. Med., 117, 224.

\title{
NEPHROTIC SYNDROME DUE TO THROMBOSIS OF THE INFERIOR VENA CAVA AND RENAL VEINS
}

\author{
T. J. BAYLEY, M.B., M.R.C.P. \\ Donald Heath, M.D., Ph.D., M.R.C.P. \\ J. HaRdwiCKe, M.D., B.Sc. \\ A. G. W. WHITFIELD, M.D., Ph.D., F.R.C.P \\ Departments of Medicine, Pathology and Experimental Pathology, Queen Elizabeth Hospital, \\ University of Birmingham.
}

FIFTY years ago, Rowntree, Fitz and Gerachty (1913) described the proteinuria which occurred in animals following obstruction of the inferior vena cava proximal to the renal veins or of the renal veins themselves. In the same year Shattock (1913) recorded the case of Dr. Rivers Pollock, the obstetric physician to the Westminster Hospital, who sustained a traumatic thrombosis of the inferior vena cava and thereafter had gross albuminuria which persisted until his death 25 years later from streptococcal septicæmia. It was not until 1939 that the first full description of the nephrotic syndrome associated with thrombosis of the renal veins and inferior vena cava appeared (Derow, Schlesinger and Savitz, 1939). Since then other cases have been recorded (Blainey, Hardwicke and Whitfield, 1954; Harrison, Milne and Steiner, 1956; Pollak, Kark, Pirani, Shafter and Meuhrcke, 1956; Hasson, Berkman, Parker and Rifkin, 1957; Blainey, Brewer, Hardwick and Scothill, 1960). This communication describes a further patient observed closely from onset to death from uræmia eight years later and in whom there were many features of particular interest.

\section{Case Report}

In April 1955 a previously fit male aged 27 years used a breast drill from the right groin for some hours and the following day he experienced a severe aching pain in this region. Twenty four hours later the whole of the right leg became swollen and he wass admitted to the Royal Salop Infirmary where he wasgiven ten days heparin therapy under which the pain and swelling subsided. Two weeks later œdema of the right leg recurred and he was given anticoagulant therapy with phenindione for seven weeks after which he returned to work and wore an elastic stocking은 In December 1955 the left leg became odematous and he was re-admitted to the Royal Salop Infirmary Massive albuminuria was found, phenindione therapy was recommenced and on 17th March, 1956 he was transferred to the Queen Elizabeth Hospital, Birming ham. At this time collateral venous channels wereevident on the trunk (Fig. 1) and both legs and the lumbo-sacral region of the back were grossly? œedematous. The blood pressure was $135 / 80 \mathrm{~mm}$. Hg尺 The urinary protein loss fluctuated between 9 and $15 \mathrm{~g}$. daily and the deposit showed $1143 \times 10^{\circ}$ red blood cells, $15 \times 10^{8}$ white blood cells, $0.2 \times 105$ hyaline casts and $0.1 \times 10^{6}$ granular casts in twenty four hours (Fig. 2). The blood urea was $35 \mathrm{mg}$. 1100 $\mathrm{ml}$. and the creatinine clearance $119 \mathrm{ml}$./min. The serum cholesterol was $370 \mathrm{mg} . / 100 \mathrm{ml}$. and the serum protein $5.3 \mathrm{~g} . / 100 \mathrm{ml}$. of which the albumiñ was $2.20 \mathrm{~g} . / 100 \mathrm{ml}$. The serum complement fluctuated between 0.8 and 1.0 units $/ \mathrm{ml}$. The chest radiograplu showed a normal cardiac silhouette and clear lung fields. An intravenous pyelogram revealed no abnormality apart from rather dense renal shadow

Renal biopsy showed no normal glomeruli. In ald there was some degree of hyalinisation patchily distributed within the glomeruli. Glomerularo adhesions and periglomerular fibrosis were presen? in some glomeruli. The tubules were mainly normag 